\title{
National Principles of Democracy in Uzbekistan
}

Turdiyev Bexruz Sobirovich

A Doctor of Philosophy (PhD) in Philosophical Sciences, Bukhara State University, Bukhara City, Uzbekistan.

DOI: http://doi.org/10.46382/MJBAS.2021.5307

Copyright: () 2021 Turdiyev Bexruz Sobirovich. This is an open access article distributed under the terms of the Creative Commons Attribution License, which permits unrestricted use, distribution, and reproduction in any medium, provided the original author and source are credited.

Democracy is not only a political and legal phenomenon, but also a high value associated with high spirituality, rich culture, personal maturity, which determines the spiritual and moral condition of every citizen. If we compare Eastern and Western democracies, unlike its Western democracies, the change of the world, of social life, begins first in man, in his spiritual world. This article provides a scientific analysis of the specifics of Eastern democracy in the development of man, his spiritual world and the building of a democratic society.

Keywords: Democracy, Civil society, Identity, Sovereignty, People, Human rights, Values, Culture, Innovation, Rhetoric, Equality, Pluralism, Civilization, Patriotism, Traditions, Spiritual heritage, Humanity, Alla (Creddle Song), Eastern code, Faith, Homeland, Integration.

\section{Introduction}

Democracy is the highest criterion by which a person expresses his freedom, equality, dreams and happy life since the period of development, when the conscious life of members of society began in the history of mankind as a whole. It is not only a political and legal reality in our lives, but also a high value associated with high spirituality, cultural uplift, personal perfection, reflecting the moral and spiritual qualities of person.

Today, the universal aspects of democracy are recognized as a fundamental principle of world development, representing a set of basic, universally recognized signs and characteristics inherent in democratic processes. Its common aspects are to ensure the independence of peoples and states, to strengthen it, to establish relations between states, to move from a strong state to a strong civil society, to develop it in line with modern requirements.

\section{Literature Review}

Today, the system of views on the form, content and role of democracy in human development is enriched and refined in the process of increasing the experience of advanced statehood in the world, understanding the identity and future of peoples. We can see the descriptions of such diverse general principles of democracy in the interpretation of the following philosophers.

\section{Main Part}

Todd Landman, Professor and Vice Rector for Political Science, in charge of the Faculty of Social Sciences at the University of Nottingham in his book Human Rights and Democracy, he dwells on the general laws of modern democracy, arguing that "modern conceptions of democracy are based on the fundamental ideas of popular sovereignty and collective decision-making in which rulers are in some way held to account by those over whom they rule" [1]. In this definition, it is fair to mention that democracy must first and foremost take into account the interests of the people, and the government must serve the public interest and serve their common interests in its activities. 
Philosopher Jean-Aime Raveloson, the Friedrich-Ebert-Stiftung's national representative in Madagascar, describes democracy as "To put it another way we can say that a government comes from the people; it is exercised by the people, and for the purpose of the people's own interests" [2].

Democracy, means living in accordance with universal law that protects the human rights and interests of the state for all. Furthermore, the democratic system that exists in each country is shaped by the way of life formed on the basis of the thinking, historical traditions and values of that nation.

German researcher Angelika Klein says "democracy is this - more than just a set of specific government institutions; it rests upon a well understood group of values, attitudes, and practices - all of which may take different forms and expressions among different cultures and societies around the world" [3].

In other words, at the heart of democracy is, first of all, human spirituality, its high moral and ethical image, the culture of its democracy and the extent to which it can use its principles. It is a set of well-understood values, relationships that can take different forms and expressions between different cultures and societies of the world.

Minoru Tsubogo, a Japanese scholar and professor at Waseda University, describes democracy as an innovative form of governance in his comparative research on democracy in Germany and Japan: "Innovation in the democratic system in this context refers to the enactment of innovative means of governance and policy formation via initiatives, referendums, deliberations, and citizen activities, thereby strengthening the democratic process and the democracy as a whole" [4]. Therefore, democracy is not an event that is built or transferred all at once. Perhaps we can say that it is a constantly evolving reality. At the same time, it is formed and developed under the influence of spiritual renewal and political change, and acquires a new meaning in the new era. So, proceeding from the definition of Minoru Tsubogo, we can describe democracy as a process in which a person develops, becomes rich in content and develops form.

Another Japanese scholar, Atsuko Geiger, argues that "On the broader issue of political rhetoric, while "democracy" as a concept is commonly accepted as a vital part of Japanese politics and foreign policy, in foreign policy speeches, politicians often use terms such as "universal values" or "shared values" when discussing democracy" [5]. In the same sense, based on the above definition, we can say that democracy is the basis of advanced experience and universal values accumulated by the developed nations of the world.

Wen Jiabao, a Chinese politician who served as the sixth prime minister of the State Council of the People's Republic of China and the head of the Chinese government, described democracy as follows: "Democracy, law, freedom, human rights, equality, and fraternity are not characteristics unique to capitalism. They are the shared fruits of civilization that have come into being in the history of the whole world and are among the values that mankind has collectively pursued" [6]. Indeed, human rights and freedoms based on democracy, the rule of law, the recognition of the rule of law, inter-ethnic tolerance and mutually beneficial cooperation, political pluralism, and spiritual renewal are all integral parts of universal values.

Professor Nikolai Baranov, a Russian political scientist and doctor of political sciences, says: "democracy comes from the people themselves, it is served by the people and for the interests of the people. The description of 
democracy as a "power for the people" implies a future in which democracy is understood as the goal of the state through political and social action" [7]. So, in accordance with this definition, we will not be mistaken if we say that democracy is a way of the future for the people and relying on its power, supporting the interests of the people.

In a book edited by Professor I. Yu. Jurgens, Chairman of the Board of the Institute for Modern Development, the authors describe democracy as follows: "Of course, democracy, this is primarily the creation of state institutions that existed and developed at the right time. Secondly, democracy is the rule of law that must be ensured. Thirdly, the most important thing in a democracy is the responsibility of the government to those who elect it" [8].

Rightfully, the authors provide for the active participation, support and rule of law of the people in public administration on the basis of three pillars of democracy, the direct or indirect participation of the people in it. Therefore, it is fair to say that democracy is a phenomenon that rationally organizes the socio-political movement aimed at improving the lives of the people. While Western democracy, which is recognized as a great achievement of world civilization, is a collection of advanced practices, Eastern democracy is rich in ancient traditions and values in the field of governance, its unique views and experiences reflect its distinctive features.

\section{Theoretical Background}

\section{The following are the specific aspects of the peoples of Central Asia that unite them in their democratic governance:}

First, the peoples of Central Asia have a strong loyalty and respect for their homeland. In the East, the homeland has long been considered sacred for everyone who realizes his identity. Every herb, a drop of water, and a handful of soil is honored. It is our great and priceless treasure that cannot be exchanged for anything in the world [9]. In the peoples of Central Asia, it is a sacred duty to love one's homeland, to honor it, to be proud of it, to sacrifice one's happiness. If we look at the history of the peoples of the region, we can see the incarnation of a great patriotism on the basis of the valiant actions carried out by Tomaris, Shirak, Spitamen, Muqanna, Jalaluddin Manguberdi and many other ancestors on the basis of their loyalty to their native land, protecting it from the enemies for their own sake, and its independence and prosperity.

Secondly, the greatness of the memory of the ancestors, the unconditional respect for the traditions, customs and spiritual and cultural heritage left by them by the representatives of future generations. Understanding the rich history of the people, preserving national values, respecting the heritage of our ancestors who have made a worthy contribution to the civilization of world culture and its comprehensive development are of great importance in the spiritual and moral enrichment and development of society.

The peoples of Central Asia have unique values, customs and traditions, rich and instructive historical memory, unique scientific, cultural and spiritual heritage. The inculcation of feelings of family, parents, mahalla, kindness, patriotism, dear to the peoples of the region, in the hearts and minds of the younger generation, was carried out in harmony with the spiritual heritage left by their ancestors in the process of national democratic development. This region has a rich spiritual heritage, which gave the world such great thinkers as Farabi, Ibn Sina, Beruni, Khorezmi, Alisher Navai. 
Thirdly, sincerity, openness, hospitality and respect are the priorities of moral values in interpersonal communication. The wonderful qualities of the peoples of Central Asia, such as humanity, purity of heart, hospitality, kindness, have been ingrained in their blood for thousands of years and have taken a firm place in the life of the people. Such high human qualities of the people serve the rise of social life, moral development.

In particular, such qualities as sincerity, purity of heart, openness are invaluable qualities of the peoples of the region, which arise from the pursuit of goodness. On the basis of these qualities, the peoples of the region live by honest labor, avoid greed and filth, be patient in any situation, always be kind and gentle in human relations, be compassionate, honest and pious.

Also, the respect of children for parents is one of the distinctive features of Eastern democracy. In the East, the children, from a young age, leaned on their father, listened to his mother's Alla (Creddle song) and grew up at their mercy. As the thinker Alisher Navai said, the mother was known as the moon and the father as the sun. Such respect for parents is formed in the family [10].

Fourthly, the fact that the Eastern Code of Ethics, which has always been respected, preserves such moral norms as modesty, timidity, perseverance, and humility. In Eastern democracy, moral education is multifaceted, in which a person's true humanity is measured by its simplicity, its faith and piety, and the predominance of feelings of honor and modesty. After all, these qualities are valued in the East as a sign of spiritual beauty, perfection and glory.

In the east, people faith is considered in the desire of a person for high humanity, perfection at every moment. And the basis of faith is considered to be in piety. In the peoples of the region, piety is the fear of Allah when doing wrong, and abstaining from evil deeds. The God-fearing servant lives honestly in the family and society, will be right, will not bribe, will not swear, will not deceive anyone, will not lie, will not betray people, country, and so on. Shame is also a sign of faith [11].

Shame in the peoples of Central Asia, in the virtues of unassertiveness, reflects the ability of a person to protect himself from inappropriate and bad behavior, his sense of shame.

This quality expresses a person's responsibility to his conscience, his religion, for his wrongdoing. In the spirituality of the peoples of Central Asia lies not only the concept of chastity, purity, but also the sense of glorification of the person and his family, ancestors, honor, dignity and name of his homeland, the qualities of non-repugnance.

It should be noted that in the moral values of the peoples of the region, the feelings of modesty, honor and patriotism are highly valued, and they consider it a shame for their families, mahallas and lands to be discriminated against by others. In the East, the protection of the honor of the family and the homeland has been valued as a shining expression of the virtue of modesty.

\section{Results}

Thus, with the above distinct aspects of our national spirituality, Eastern democracy is drastically different from Western democracy. In today's integration process, the specific democratic values of the East are becoming more 
prominent. Through these aspects, Uzbekistan is evolving from a national revival to a national upsurge, a process of renewal.

\section{Conclusion}

In conclusion, the development of democratic processes in Uzbekistan testifies to the changes in the worldview of citizens, the growth of political and legal culture and the renewal of their spiritual image, as well as the support of these processes by the Uzbek people. This process is a unique value, a high democratic reality.

\section{Declarations}

\section{Source of Funding}

This research did not receive any grant from funding agencies in the public, commercial, or not-for-profit sectors.

\section{Competing Interests Statement}

The author declares no competing financial, professional and personal interests.

\section{Consent for publication}

Author declares that he/she consented for the publication of this research work.

\section{References}

[1] Todd Landman, Human Rights and Democracy, London, Bloomsbury Academic, 2013, P.26.

[2] Jean-Aime Raveloson, What is democracy?, Antananarivo, KMF-CNOE \& Nova Stella, 2008, P.4.

[3] Angelika Klein, Concepts and principles of democratic governance and accountability, Uganda, KonradAdenauer-Stiftung, 2011, P.3.

[4] Minoru Tsubogo, The Role of Civil Society and Participatory Governance in Japanese Democracy, Japanese political science review, 2 (2014), P.40.

[5] Atsuko Geiger, Japan's support for democracy-related issues, Japan Center for Int. Exchange, 2019, P.13.

[6] Wen Jiabao in a 2005 press conference, cited in Yang Dali, China's Long March to Freedom, Journal of Democracy 18, No. 3, (July 2007): 61.

[7] Baranov N.A., Sovremennaya demokratiya: evolyutsionniy podxod, Sankt-Peterburg, BGTU, 2008, P.17.

[8] Yurgens I.YU., Demokratiya: razvitie Rossiyskoy modeli, Moskva EKONINFORM, 2008, P.15.

[9] Go’zal va betakrorimsan, muqaddas Vatanim, jonim senga fido, O’zbekistonim Ma'naviy hayot, 2, 2016, P.6. [10] Umarov E., Abdullaev M., Ma’naviyat asoslari. T., Sharq, 2005, P.88.

[11] Ikramov Sh.T., Yuksak ma'naviyat va qonun ustuvorligi asosida yashash, elyurtga sadoqat, adolat, halollik fazilatlarini va muomala madaniyatini kamol toptirish. T., O’zbekiston Respublikasi IIV Akademiyasi, 2014.

[12] Turdiyev Bexruz Sobirovich (2019), The role of national harmony in the Strategy of spiritual renewal, Scientific Bulletin of Namangan State University, Vol. 1, 2019, Iss. 6, P. 229-233.

[13] Turdiyev Bexruz Sobirovich, Strategy of Renewal of National Spirituality of Uzbekistan, International Journal on Integrated Education, Volume 3, Issue VIII, August 2020, P. 122-126. 